\title{
Liharotuisten nautojen rehunhyväksikäyttö ja residuaalinen syönti
}

\author{
Maiju Pesonen \\ Maa- ja elintarviketalouden tutkimuskeskus, Kotieläintutkimus, Tutkimusasemantie 15, 92400 Ruukki, \\ maiju.pesonen@mtt.fi
}

\section{Tiivistelmä}

Perinteisesti rehujen hyväksikäyttö on ilmoitettu rehunmuuntosuhteella. Rehunmuuntosuhteessa ei oteta huomioon yksilöiden välisiä eroja ylläpitoon ja kasvuun tarvittavassa energianmäärässä. Rehunmuuntosuhteella on vahva yhdysvaikutus eläimen kasvuominaisuuksien ja aikuiskoon kanssa. Rehukustannukset muodostuvat kookkaammilla eläimillä suuremmiksi, vaikka niiden kasvuominaisuudet olisivat ylivertaisia. Emolehmätuotannossa eläinten hedelmällisyys on tuotannon avaintekijöitä. Elopainoltaan kookkaampien eläinten lisääntymistehokkuus on hieman alhaisempi. Tämä johtuu osittain myöhemmin saavutetusta sukukypsyysiästä. Emolehmäkarjassa rehun ja peltopinta-alan tarve lisääntyy merkitsevästi eläinten aikuiskoon kasvaessa. Tilan kokonaistehokkuus voi kärsiä suuremmasta rehukustannuksesta siitä huolimatta, että tuotantotulokset nousevat.

Residuaalinen syönti on erotus, joka muodostuu eläimen todellisesta syönnistä ja arvioidusta syönnistä saavutettua tuotantotulosta kohden. Laskentatavasta johtuen residuaaliseen syöntiin ei vaikuta eläimen koko tai tuotanto-ominaisuudet. Residuaalisen syönnin yhdysvaikutus eläimen aikuiskoon ja kasvuominaisuuksien kanssa on hyvin pieni tai sitä ei ole havaittu. Residuaalisen syönnin avulla on mahdollista löytää ne yksilöt, jotka ovat syövät vähemmän rehua ja ovat tuotannollista ominaisuuksilta tasavertaisia. Residuaalinen syönti periytyy keskinkertaisesti.

Fysiologisesti residuaaliseen syöntiin vaikuttavat rehun syönti ja sulatus, aineenvaihdunta, fyysinen aktiivisuus ja lämmönsäätely. Residuaalisella syönnillä on taloudellinen ja ympäristövaikutus. Emolehmäkarjan ylläpitoenergiantarvetta voidaan vähentää $9-10 \%$ valitsemalla matalan residuaalisen syönnin omaavia eläimiä. Loppukasvatuksessa eläinten kuiva-aineen syönti on ollut matalan residuaalisen syönnin eläimillä keskimäärin $12 \%$ matalampi ja rehunmuuntosuhde $9-15 \%$ tehokkaampi kuin korkean residuaalisen syönnin eläimillä. Sonnan määrää sekä ravinnepäästöjä voidaan vähentää $15-17 \%$ valitsemalla matalan residuaalisen syönnin omaavia eläimiä. Australialaisissa ja Pohjoisamerikkalaisissa tutkimuksissa matalan residuaalisen syönnin eläinten metaanintuotanto on ollut 25 30 \% vähäisempää kuin korkean residuaalisen syönnin eläimillä. Teurasruhot ovat olleet hieman vähärasvaisempia matalan residuaalisen syönnin eläimillä korkean residuaalisen syönnin eläimiin verrattuna. Vähärasvaisuus voi aiheuttaa negatiivisia vaikutuksia emojen hedelmällisyyteen. Matalan residuaalisen syönnin emot ovat poikineet 5- 6 päivää myöhemmin kuin korkean residuaalisen syönnin emot.

Residuaalisen syönnin määritys vaatii 70 päivän koejakson, jossa mitataan eläimen päivittäinen syönti ja kasvu. Geenitesti vähentää kustannuksia rehunhyötysuhteeltaan erinomaisten eläinten tunnistamisessa.

Asiasanat: Naudanlihantuotanto, rehunhyötysuhde, residuaalinen syönti 


\section{Johdanto}

Rehut muodostavat 3/4 naudanlihantuotannon muuttuvista kustannuksista. Naudoilla ylläpitoenergian osuus on korkea. Syödystä rehusta $70-75 \%$ menee ylläpitotarpeen täyttämiseen. Naudanlihantuotannossa rehunmuuntosuhde myytäväksi lihaksi on valitettavan alhainen. Rehujen energiasta vain $6 \%$ käytetään lopputuotteen eli lihaksen muodostamiseen (vrt. sianlihantuotannossa $15 \%$ ja siipikarjanlihantuotannossa $20 \%$ ) (Lobley 2003). Tuotantokustannuksia voidaan alentaa tehokkaammalla rehujen hyväksikäytöllä. Rehunhyötysuhteen parantaminen viidellä prosentilla on neljä kertaa kannattavampaa kuin päiväkasvun nostaminen 5 \% (Okine ym. 2003). Residuaalinen syönti (RFI) on yksi mahdollinen rehunhyötysuhteen mittausmenetelmä. Residuaalisen syönnin etuna on, ettei se ole riippuvainen tuotannontasosta. Residuaalinen syönti on keskinkertaisesti periytyvä ominaisuus, joten jalostuksellisella valinnalla pystytään vaikuttamaan rehunhyötysuhteeseen. Residuaalisen syönnin mittaaminen voidaan suorittaa kasvavilla eläimillä. Testaaminen on kuitenkin hyvin kallista. Geenimarkkeriavusteinen valinta voi tuoda taloudellisia säästöjä rehunhyötysuhteeltaan tehokkaampien eläinten valitsemiseen. Periytyvyytensä ansioista tämän pitäisi vähentää myös emolehmäkarjan rehukustannuksia.

\section{Residuaalinen syönti}

Koch ym. (1963) esittivät määreen residuaalisesta rehunhyötysuhteesta tai residuaalisesta päiväkasvusta, joka ei ole riippuvainen eläimen yksilöllisistä kasvuominaisuuksista tai syönnistä. Nykyään termiä kutsutaan residuaaliseksi syönniksi. Residuaalinen syönti määritetään eläimen syömän rehunmäärän ja arvioidun syönnin erotuksena. Arvio syönnistä muodostetaan eläimen elopainon ja tuotannon perusteella. Määritelmän mukaan negatiivinen residuaalinen syönti (- RFI) merkitsee tuotannollisesti tehokkaampaa eläintä, koska sen syönti on ollut oletettua syöntiä pienempi suhteessa eläimen kokoon ja tuotantoon. Positiivinen residuaalinen syönti (+ RFI) määrittää tuotannollisesti vähemmän tehokkaan eläimen, koska se on syönyt suhteessa enemmän rehua kuin on oletettu sen kokoon ja tuotantoon nähden. Laskentatavasta johtuen residuaaliseen syöntiin ei vaikuta eläimen koko tai tuotantoominaisuudet, kuten kasvutapa (Archer ym. 1999). Residuaalisella syönnillä on yhdysvaikutus rehunmuuntosuhteen kanssa. Rehunmuuntosuhteeltaan tehokkaiden eläinten residuaalinen syönti on alhainen (Nkrumah ym. 2004). Jalostuksellinen valinta residuaalisen syönnin perusteella ei vaikuta eläimen aikuiskokoon tai kasvutapaan, kuten päiväkasvuun (Herd \& Bishop 2000). Se mahdollistaa kuitenkin niiden yksilöiden löytämisen, jotka ovat syövät vähemmän rehua ja ovat tuotannollista ominaisuuksilta tasavertaisia. Residuaalista syöntiä pidetään nykytutkimuksen mukaan sopivampana määreenä arvioimaan rehunhyötysuhteen geneettistä muutosta kuin perinteistä rehunmuuntosuhdetta. Residuaalinen syönti on muutamissa tutkimuksissa arvioitu myös tarkimmaksi rehunhyötysuhteen määreistä (Arthur ym. 2001b, Nkrumah ym. 2004).

\section{Residuaalisen syönnin fysiologia}

Rehunhyötysuhteeseen vaikuttavia tekijöitä säädellään joko koko eläimen tai vain solun tasolla. Residuaalisen syönnin vaihteluun vaikuttaa viisi fysiologista päätekijää (Herd \& Arthur 2009). Ne liittyvät rehun syöntiin ja sulatukseen, aineenvaihduntaan, fyysiseen aktiivisuuteen ja lämmönsäätelyyn. Kokeellisesti on arvioitu, että eri tekijöiden osuudet olisivat: 1 . Valkuaisaineenvaihdunta, kudosmetabolia ja stressi $37 \%, 2$. Rehunsulatus $10 \%, 3$. Muuntumistappio ja fermentaatio $9 \%$, 4. Fyysinen aktiviteetti $9 \%$, 5. Kehon koostumus $5 \%$ ja 6. Syöntikäyttäytyminen $2 \%$. Vielä tuntemattomien tekijöiden osuudeksi arvioidaan $27 \%$. Näiden oletetaan jakautuvan tasaisesti yllä esitettyjen tekijöiden kesken. Residuaaliseen syöntiin arvioidaan vaikuttavan yli 100 geeniä (Herd \& Arthur 2009). Erilaisten geenimarkkereiden löytäminen vähentää kustannuksia rehunhyötysuhteeltaan erinomaisten yksilöiden tunnistamisessa.

Rasvan ja lihaskudoksen jakautuminen on erilainen kasvavalla eläimellä kuin aikuiskoon jo saavuttaneella eläimellä. Valkuaisaineiden muodostuminen (proteiinisynteesi) on nuorella eläimellä tehokkaampaa kuin rasvan muodostuminen. Valkuaisaineenvaihdunta ja kasvu hidastuvat, kun eläin saavuttaa sukukypsyysiän. Aikuisella eläimellä ylläpitotarve valkuaisen suhteen on suurempi kuin rasvan. Tämä suosii rasvan muodostumista elimistöön. Rasvan muodostuminen vaatii paljon energiaa, joten rehunhyötysuhde laskee sekä residuaalinen syönti nousee (Tixier-Boichard ym. 2002). Residuaalisen syönnin määritykset on pääasiallisesti tehty nuorilla, kasvavilla eläimillä. Yhdysvaikutukset residuaalisen syönnin ja kehon koostumuksen kanssa ovat olleet melko selviä. Energian muuntosuhteel- 
taan tehokkailla eli alhaisen residuaalisen syönnin eläimillä muodostuu vähemmän rasvaa (Schenkel ym. 2003, 2004, Nkrumah ym. 2004, Moore ym. 2005).

Syöntikäyttäytymisellä ja residuaalisella syönnillä on havaittu yhteys. Korkean residuaalisen syönnin (vähemmän tehokkaat) eläimet syövät alussa tiheämmin, mutta syöntikerrat vähenivät kasvatusvaiheen loppua kohden. Matalan residuaalisen syönnin (rehunhyötysuhteeltaan tehokkaammat) eläinten syöntikäyttäytyminen oli tasaisempaa (Richardson \& Herd 2004, Dobos \& Herd 2008). Korkean residuaalisen syönnin eläimet käyttävät enemmän aikaa syömiseen. Ne vierailevat useammin ruokintapaikalla ja syövät nopeammin. Syöntikäyttäytyminen on keskinkertaisesti periytyvä ominaisuus (Robinson \& Oddy 2004, Lancaster ym. 2009). Oletetaan, että syöntikäyttäytymiseen vaikuttaa samoja geenejä, joilla on vaikututusta myös residuaalisen syönnin muodostumiseen.

Perimä vaikuttaa eläinten kykyyn kestää stressiä. Stressin fysiologisiin oireisiin kuuluvat kohonnut aineenvaihdunnantaso ja lisääntynyt energiankulutus. Elimistö kuluttaa rasvakudosta ja lihaksen valkuaisvarastoja hajotetaan (Gupta ym. 2004, Knott ym. 2008). Plasman kortisolipitoisuus sekä muutamat puna- ja valkosoluindikaattorit ovat yhteydessä eläimen kokemaan stressin määrään (Gupta ym. 2005). Korkea residuaalisen syönnin (matala rehunhyötysuhde) härillä on havaittu kohonneita kortisoli- sekä puna- ja valkosoluindikaattoripitoisuuksia (Richardson ym. 2004).

Erot aineenvaihdunnassa voivat vaikuttaa eläinten lämmöntuottoon ja energian hyväksikäyttöön. Ylläpitoenergian tarpeen ja eläimen tuottaman lämmön välillä on havaittu yhteys. Nuorilla liharotuisilla sonneilla havaittiin, että geneettinen vaihtelu ylläpitoenergian tarpeen ja residuaalisen syönnin välillä oli samansuuntainen (Herd \& Bishop 2000). Eläin, joka tuottaa enemmän lämpöä samanlaisella dieetillä, tarvitsee enemmän energiaa ylläpitoon (Derno ym. 2005). Silmästä, poskesta ja jaloista mitattu pintalämpötila on yhdistetty eläimen rehunhyötysuhteeseen. Liharotuisilla sonneilla matalampi lämpötila on merkinnyt matalampaa residuaalista syönti eli tehokkaampaa rehun hyväksikäyttöä (Montanholi ym. 2009).

\section{Residuaalisen syönnin tuotantovaikutukset}

Kasvavien liharotuisten nautojen residuaalisen syönnin eroja on tutkittu suhteellisen paljon. Keskimäärin kuiva-aineen syöntimäärä on ollut $1,5-3,0 \mathrm{~kg} \mathrm{ka} / \mathrm{d}$ pienempi matalan residuaalisen syönnin eläimillä. Päiväkasvut ovat olleet samansuuruisia sekä matalan että korkean residuaalisen syönnin eläimillä (Nkrumah ym. 2004, 2007, Vinet ym. 2008, Kelly ym. 2009, Lawrence ym. 2009). Kehon rasvan määrän ja residuaalisen syönnin välillä on liharotuisilla naudoilla geneettinen yhteys. Suurempi kehon rasvan määrä heikentää residuaalisen syönnin tulosta. Matalan residuaalisen syönnin eläimet ovat vähärasvaisempia, niiden selkälihaksen pinta-ala on suurempi sekä rehunmuutosuhde on parempi kuin korkean residuaalisen syönnin eläimillä (Herd ym. 2003, Nkrumah ym. 2007, Lancaster ym. 2009). Teurasruhojen rasvan määrä voi vähentyä $(5 \pm 2 \%)$, jos jalostuksellisena valinta perusteena käytetään residuaalista syöntiä. Teurassaannon ja lihaksen osuuden on arvioitu lisääntyvän noin $1 \%$, jos eläinaineksen valintaan käytetään residuaalista syöntiä (Nkrumah ym. 2007).

Rasvoittuminen on kaksiteräinen miekka residuaalisen syönnin suhteen. Aikuisilla eläimillä, tässä tapauksessa emolehmillä, energeettinen tehokkuus on päinvastainen verrattuna kasvaviin eläimiin. Emolehmä, joka pystyy tehokkaasti keräämään rasvavarastoja ja säilyttämään hedelmällisyytensä rajallisella rehumäärällä, on tehokas (Jenkins \& Ferrell 2002, 2007, Johnson ym. 2003). Ylläpitokaudella emolehmät tarvitsevat enemmän rehun energiaa valkuais- kuin rasva-aineenvaihdunnan ylläpitoon. Emolehmä, jolla on suhteessa enemmän lihasmassaa ja vähemmän rasvaa, tarvitsee enemmän rehunenergiaa elopainon säilyttämiseen. Energiantarve (ME, MJ) yhden lihaksen valkuaismassakilogramman ylläpitoon on 9,3 kertaa suurempi kuin rasvakilogramman (DiCostanzo ym. 1990). Täysikasvuisilla emolehmillä on havaittu 23 - $29 \%$ vaihtelu ylläpitoenergian tarpeessa, joka on riippumaton eläimen elopainosta (DiCostanzo ym. 1990, Bailey ym. 2008, Prado-Cooper ym. 2009).

Residuaalisella syönnillä on suurin merkitys emojen ylläpitokauden rehun kulutukseen. Maidontuotantokaudella erot eivät ole kokeissa olleet yhtä merkitseviä. Matalan residuaalisen syönnin emolehmät söivät keskimäärin $0,7-1,5 \mathrm{~kg}$ ka/d vähemmän kuin korkean residuaalisen syönnin emot (Arthur ym. 1999, 2005, Basarab ym. 2007, Meyer ym. 2008, Lawrence ym. 2009). Emolehmien painossa tai kuntoluokassa ei ole ollut eroja suhteessa residuaaliseen syöntiin (Basarab ym. 2007, Meyer ym. 2008, Lawrence ym. 2009). Täysikasvuisilla emolehmillä on ollut samanlainen tuotannon taso riippumatta residuaalisen syönnin tuloksesta. Tiinehtymisten ja vieroitettujen vasikoiden lukumäärässä eikä maidontuotannossa ole havaittu eroja (Arthur ym. 2005, Basarab ym. 2007). Matalan residuaalisen 
syönnin emot kuitenkin poikivat 5-6 päivää myöhemmin kuin korkean residuaalisen syönnin emot (Arthur ym. 2005, Basarab ym. 2007). Poikima-ajan siirtyminen myöhemmäksi osoittaa, että matalan residuaalisen emot tiinehtyvät myöhemmin kuin korkean residuaalisen syönnin emot. Tuotannollisesti tehokkaan emolehmän pitäisi poikia vuosittain samaan aikaan. Varsinkin tavoiteltaessa lyhyttä, 60-80 päivän poikima-aikaa, poikima-ajan siirtyminen on epäedullinen ominaisuus. Matalan residuaalisen syönnin jälkeläisiä tuottavat emot poikivat vähemmän kaksosia (Basarab ym. 2007). Matalan residuaalisen syönnin eläinten jalostuskäytössä pitäisi kiinnittää erityishuomio uudistushiehojen ja sonnien hedelmällisyysominaisuuksiin (Nkrumah ym. 2004, Arthur ym. 2005, Basarab ym. 2007).

\section{Residuaalinen syönti ja ympäristövaikutukset}

Australialaisissa ja Pohjoisamerikkalaisissa tutkimuksissa matalan residuaalisen syönnin eläimet (tehokkaampi rehunhyötysuhde) ovat tuottaneet 25 - 30\% vähemmän metaania ja 15 - $20 \%$ vähemmän lantaa verrattuna korkean residuaalisen syönnin eläimiin. Lisäksi sonnan sisältämät typen, fosforin ja kaliumin määrä ovat olleet 15 - 17 \% pienempiä matalan residuaalisen syönnin eläimillä (Nkrumah ym. 2006, Hegarty ym. 2007). McDonnell ym. (2009) eivät saaneet maissisäilörehulla ja ohrapohjaisella väkirehulla (30:70) vastaavia eroja eläinten metaanintuotannossa. Mekanismeja, jotka ovat syöntimäärästä riippumattoman alhaisemman metaanintuotannon takana, ei tunneta. Alhaisempi metaanintuotanto voi johtua eläinten erilaisesta kyvystä metabolisoida rehun energiaa, toisaalta se voi johtua eläinten yksilöllisestä vaihtelusta metaanintuotannossa (Nkrumah ym. 2006). Alhaisemman metaanin tuotannon on arveltu myös johtuvan pötsin erilaisesta mikrobipopulaatiosta. Mikrobipopulaation erilaisuus voi olla perinnöllinen ominaisuus. Krueger ym. (2009) eivät kuitenkaan pystyneet osoittamaan eroja metaania tuottavien mikrobien lukumäärässä matalan ja korkean residuaalisen syönnin eläinten välillä. Pienempi rehunsyöntimäärä on päätekijä pienempään lannan tuotantoon (Pinares-Patiño ym. 2004, Nkrumah ym. 2006, Hegarty ym. 2007). Jalostuksellinen valinta paremman rehunhyötysuhteen puolesta voi laskea naudanlihantuotannon ympäristöpäästöjä.

Käytettäessä residuaalista syöntiä yhtenä jalostuksellisen valinnan perusteena sama tuotannon taso saavutetaan pienemmällä kasvibiomassalla. Tällöin peltopinta-alan tarve eläinyksikköä kohden pienenee, ja tuottajille muodostuu suurempi joustavuus ohjata tuotantoaan. Alueilla, joilla on mahdollista lisätä tuotantoa, voidaan samalla rehumäärällä kasvattaa enemmän eläimiä. Toisaalta intensiivisemmän naudanlihantuotannon maissa pystytään ympäristöä säästämään (Herd ym. 2003, Herd \& Arthur 2009).

\section{Jalostukselliset mahdollisuudet}

Jalostuksessa voidaan käyttää ominaisuuksia, joilla on geneettistä vaihtelua ja jotka ovat periytyviä. Residuaalisen syönnin periytyvyysaste on keskimäärin 0.39 (Herd \& Bishop 2000, Arthur ym. 2001a, b, Schenkel ym. 2003, Vinet ym. 2008). Yhdysvaikutus lehmävasikan ja emolehmän residuaalisen syönnin kanssa on korkea, 0.98 (Herd ym. 2003). Residuaalisen syönnin perusteella matalaan ja korkeaan jalostuslinjaan jaetuilla liharotuisilla naudoilla on selvät määrälliset erot rehun kulutuksessa. Yhden sukupolven valinnan jälkeen rehunsyönnin ero oli $0,6 \mathrm{~kg} \mathrm{ka} / \mathrm{vrk}$ (Richardson ym. 2001) ja viiden vuoden suunnitelmallisen jalostuksellinen jälkeen rehunsyönnin ero oli $1,2 \mathrm{~kg} \mathrm{ka} / \mathrm{vrk}$ matalan ja korkean residuaalisen syönnin eläinten välillä (Arthur ym. 2001a). Päiväkasvu eläimillä oli yhtä suuri noin $1,4 \mathrm{~kg} / \mathrm{vrk}$ (Arthur ym. 2001a).

Käytännössä eläinten jalostus on edelleen valintaan perustuvaa tuotannollisten ominaisuuksien parantamista. Perimä (geenit/genotyyppi) määrää eläimen ulkonäön ja tuotanto-ominaisuudet (fenotyypin). Jalostuksen onnistuessa tuotannollisesti merkittävien geneettisten ominaisuuksien määrä populaatiossa kasvaa. Työvälineitä eläinten perinnöllisten ominaisuuksien helpompaan ja tarkempaan havaitsemiseen kehitetään paljon. Geeniteknologiaan perustuvien merkkien (markkereiden) etuna on, että eläimet pystytään testaamaan tietyn ominaisuuden suhteen riippumatta eläimen iästä. Ominaisuus on eläimen perimässä, siihen ei ole vaikuttanut ympäristö tai tuotanto-olosuhteet. Kalliita ja aikaa vieviä eläinkokeita ei tarvitse järjestää. Markkeriavusteinen valinta ja geenitestit toimivat parhaiten sellaisten ominaisuuksien havaitsemisessa, joilla on matala periytyvyys ja joita on vaikea tai kallis mitata. Toisaalta niitä voidaan hyödyntää sellaisten ominaisuuksien esiintuomisessa, joita ei yleensä saada esille ennen eläimen teurastuloksia (ruho-ominaisuudet, teurastulokset) (Moore ym. 2009). IGENITY ja Pfizer Animal Genetics tarjoavat geenitestin residuaaliselle syönnille (RFI). Residuaalisen syönnin geenitesti on ollut markkinoilla kolme vuotta. Geenitestit perustuvat paikannettuun markkeriin sekä 
otospopulaatioista kerättyyn geneettisiin ja fenotyyppisiin tietoihin. Geenitestin tarkkuudeksi luvataan noin $30 \%$.

Stressin kestokyky on avaintekijä liharotuisten nautojen energiatehokkuudessa. Korkean residuaalisen syönnin (heikompi rehunhyötysuhde) liharotuiset härät olivat useilla eri tekijöillä mitattuna alttiimpia stressille ja reagoivat herkemmin erilaisiin muutoksiin kuin matalan residuaalisen syönnin eläimet. Herkkyys ympäristössä aiheutuville muutoksille aiheutti suuremman energiantarpeen, joka heikensi tuotantoon käytettävää energiatehokkuutta (Richardson \& Herd 2004). Jalostajien pitäisi entistä enemmän keskittyä eläinten luonteen ja temperamentin arviointiin tuotanto-ominaisuuksien lisäksi.

Jalostuksellinen valinta matalan residuaalisen syönnin perusteella vähentää eläimien ylläpitoon ja kasvuun tarvittavaa rehunmäärää. Sillä ei ole vaikutusta kasvuominaisuuksiin. Eläimien päiväkasvu on joko yhtä hyvää tai parempaa kuin vertaisryhmissä. Tutkimusten valossa residuaalinen syönti tuo merkittävää etua naudanlihantuotannon kustannuskamppailuun (Herd ym. 2003, Vinet ym. 2008, Kelly ym. 2009, Lawrence ym. 2009).

Puhdasrotujalostuksen keinot ovat rajallisia ja hitaita. Tuotantomuodon energiatehokkuutta voidaan parantaa tarkoituksenmukaisella rotujen risteytyksellä. Keskikokoiset, helposti kuntonsa säilyttävät risteytysemot voidaan astuttaa pääterotujen sonneilla. Emolehmäkarjan ylläpitokustannus ei nouse ja syntyvät vasikat tuottavat vähärasvaisempia, hyviä teurasruhoja (Bennett \& Williams 1994, Jenkins \& Ferrell 2002).

\section{Yhteenveto ja johtopäätökset}

Liharotuisten nautojen rehun syönnissä ja siitä muodostuneessa tuotantotuloksessa on havaittavissa selvää perinnöllistä vaihtelua. Kaikkia rehun hyötysuhteeseen vaikuttavia fysiologisia tekijöitä ei tunneta. Tällä hetkellä arvioidaan, että eräs merkittävimmistä tekijöistä olisi eläinten stressin sietokyky. Rauhalliset eläimet kasvavat ja tuottavat paremmin kuin vaikeasti käsiteltävät eläimet. Eläinten rehun hyötysuhteen parantamisella voidaan vaikuttaa tilan taloudelliseen tulokseen ja ympäristökuormitukseen. Perinnöllisesti rehunhyötysuhteeltaan tehokkaammat eläimet saavuttavat samat tuotannolliset tulokset pienemmällä rehumäärällä, jolloin ympäristöä kuormittavien päästöjen osuus jää vähäisemmäksi.

Residuaalisen syönnin jalostuksellisella käytöllä voi olla positiivinen vaikutus eläinten lihantuotanto-ominaisuuksiin. Matalan residuaalisen syönnin eläimet ovat hieman lihaksikkaampia ja vähärasvaisempia kuin korkean residuaalisen syönnin eläimet. Teurasruhojen rasvaisuuden arvioidaan vähenevän noin $5 \%$ ja vastaavasti teurassaannon lisääntyvän noin $1 \%$, jos residuaalista syöntiä käytetään jalostuksellisessa valinnassa. Uudistuseläinten hedelmällisyysominaisuuksien kehittymiseen on kuitenkin kiinnitettävä erityishuomio.

Rehun hyötysuhde ja residuaalinen syönti on eläimen yksilöllinen ominaisuus. Rehun hyötysuhde on erilainen eri tuotantovaiheessa. Nuorilla eläimillä suurempi tuotantopotentiaali parantaa rehun hyötysuhdetta. Emolehmillä kehon kyky kerätä rasvavarastoja parantaa tuotannon kokonaistehokkuutta. Roduilla on hyvin erilaisia ominaisuuksia. Yhdestä rodusta on vaikea löytää kaikkia optimaalisia ominaisuuksia koko tuotantoketjuun. Paras tuotannollinen tehokkuus saadaan, kun rotuominaisuudet sopivat tilan olosuhteisiin parhaalla mahdollisella tavalla. Rotujen suunnitelmallinen risteytys on tehokkain tapa yhdistää rotujen parhaita ominaisuuksia. Rehun hyötysuhde ja residuaalinen syönti periytyy keskinkertaisesti. Residuaalisen syönnin testaus on kallista ja aikaa vievää. Geenitesti tulee olemaan varteenotettava vaihtoehto rehun hyötysuhteeltaan tehokkaampien eläinten tunnistamisessa.

\section{Kirjallisuus}

Archer, J. A., Richardson, E.C., Herd, R.M. \& Arthur, P.F. 1999. Potential for selection to improve efficiency of feed use in beef cattle: A review. Australian Journal of Agricultural Research. 50:147-161.

Arthur, P. F., Archer, J.A., Herd, R.M., Richardson, E.C., Exton, S.C., Oswin, C., Dibley, C.P. \& Burton, D.A. 1999. Relationship between postweaning growth, net feed intake and cow performance. Proceedings of the Association for the Advancement of Animal Breeding and Genetics. 13: 484-487.

Arthur, P. F., Archer, J.A, Johnston, D.J., Herd, R.M., Richardson, E.C. \& Parnell, P.F. 2001a. Genetic and phenotypic variance and covariance components for feed intake, feed efficiency and other postweaning traits in Angus cattle. Journal of Animal Science. 79: 2805-2811.

Arthur, P. F., Renand, G. \& Krauss, D. 2001b. Genetic and phenotypic relationships among different measures of growth and feed efficiency in young Charolais bulls. Livestock Production. Science. 68: 131-139. 
Arthur, P.F., Herd, R.M., Wilkins, J.F. \& Archer, J.A. 2005. Maternal productivity of Angus cows divergently selected for post-weaning residual feed intake. Australian Journal of Experimental Agriculture. 45: 985993.

Bailey, C.L., Prado-Cooper, M.J., Wright, E.C., Anderson, M., Jones, R., Horn, G.W., Krehbiel, C.R. \& Wettemann, R.P. 2008. Effects of maintenance energy requirements of beef cows on cow and calf performance. 2008 Animal Science Research Reports. http://www.ansi.okstate.edu/research/.

Basarab, J.A., McCartney, D., Okine, E.K. \& Baron, V.S. 2007. Relationships between progeny residual feed intake and dam productivity traits. Canadian Journal of Animal Science. 87: 489-502

Bennett, G. L. \& Williams, B.C. 1994. Implications of genetic changes in body composition on beef production systems. Journal of Animal Science. 72:2756-2763.

Derno, M., Jentsch, W., Schweigel, M., Kuhla, S., Metges, C.C. \& Matthes, H.-D. 2005. Measurements of hest production for estimation of maintenance energy requirements of Hereford steers. Journal of Animal Science. 83: 2590 - 2597.

DiCostanzo, A., Meiske, J.C., Plegge, S.D., Peters, T.M. \& Goodrich, R.D. 1990. With-in herd variation in energy utilization for maintenance and gain in beef cows. Journal of Animal Science. 58: 2156 - 2165.

Dobos, R. \& Herd, R.M. 2008. Spectral analysis of feeding patterns of steers divergent in residual feed intake. Australian Journal of Experimental.Agriculture. 48:843-846.

Gupta, S., Early, B., Ting, S. T. L., Leonard, N. \& Crowe, M. A. 2004. Technical note: Effect of corticotrophin-releasing hormone on adrenocorticotropic hormone and cortisol in steers. Journal of Animal Science.. 82: 1952-1956.

Gupta, S., Early, B., Ting, S. T. L. \& Crowe, M. A. 2005. Effect of repeated regrouping and relocation on physiological immunological and haematological variables and performance of steers. Journal of Animal Science. 83: 1948-1958.

Hegarty, R.S., J. P. Goopy, J.P., Herd, R.M. \& McCorkell, B. 2007.Cattle selected for lower residual feed intake have reduced daily methane production. Journal of Animal Science. 85: 1479-1486.

Herd, R. M., Archer, J.A. \& Arthur, P.F. 2003. Reducing the cost of beef production through genetic improvement in residual feed intake: Opportunity and challenges to application. Journal of Animal Science. 81(E Suppl.):E9-E17.

Herd, R. M. \& Arthur, P.F., 2009. Physiological basis for residual feed intake. Journal of Animal Science. 87(E. Suppl.):E64-E71.

Herd, R.M. \& Bishop, S.C. 2000. Genetic variation in residual feed intake and its association with other production traits in British Hereford Cattle. Livestock Production Science 63: 111-119.

Jenkins, T.G. \& Ferrell, C.L. 2002. Beef cow efficiency - revisited. In: Beef Improvement federation annual meeting, 34, Omaha Nebraska, s. $32-43$.

Jenkins, T.G. \& Ferrell, C.L. 2007. Daily dry matter intake to sustain body weight of mature, nonlactating, nonpregnant cows. Journal of Animal Science. 85: 1787-1792.

Johnson, D.E., Ferrell, C.L. \& Jenkins, T.G. 2003. The history of energetic efficiency research: Where have we been and where are we going? Journal of Animal Science. 81 (E. Suppl. 1): E27-E38.

Kelly, A.K., McGee, M., Crews Jr, Boland, T.M. \& Kenny, D.A. 2009. Effect of net feed efficiency on body composition traits in growing beef heifers. Agricultural Research Forum 2009. Irish Grassland and Animal Association. p. 59.

Knott, S.A., Cummins, L.J., Leury, B.J., \& Dunshea, F.R. 2008. Less efficient rams are more responsive to adrenocorticotropic hormone (ACTH) induced stress challenge. Domestic Animal Endrocrinology. 34: 261-268.

Koch, R. M., Swiger, L.A., Chambers, D. \& Gregory, K.E. 1963. Efficiency of feed use in beef cattle. Journal of Animal Science. 22: 486-494.

Krueger, W.K., Carstens, G.E., Paddock, Z.D., Calloway, T.R., Anderson, R.C., Krueger, N.A., Gontcharova, V., Dowd, S.E., Gomez, R.R. \& Pinchard, W.E. 2009. Associations between feed efficiency and gut microbial ecology and fermentation parameters in feedlot cattle. Journal of Animal Science. E-Suppl. 2. 87: 295.

Lancaster, P.A., Carstens, G.E., Ribeiro, F.R.B., Tedeschi, L.O. \& Crews Jr, D.H. 2009. Characterization of feed efficiency traits and relationships with feeding behaviour and ultrasound carcass traits in growing bulls. Journal of Animal Science. 87: 1528 - 1539.

Lawrence, P., McGee, M., Kenny, D. A., Crews Jr, D.H. \& Earley, B. 2009. Grass silage intake, rumen and blood variable, ultrasound and body measurements and behaviour in pregnant beef heifers differing in phenotypic residual feed intake. Agricultural Research Forum 2009. Irish Grassland and Animal Association. p. 50.

Lobley, G.E. 2003. Protein turnover-what does it mean for animal production? Canadian Journal of Animal Science. 83: 327 - 340 .

McDonnell, R., Hart, K.J., Boland, T.M., Kelly, A.K., McGee, M. \& Kenny, D.A. 2009. Effect of ranking on phenotypic residual feed intake and diet on ruminal methane emissions from beef heifers. Agricultural Research Forum 2009. Irish Grassland and Animal Association p. 31. 
Meyer A. M., Kerley, M.S. \& Kallenbach, R.L. 2008. The effect of residual feed intake classification on forage intake by grazing beef cows. Journal of Animal Science. 86:2670-2679.

Montanholi, Y.R., Swanson, K.C., Schenkel, F.S., McBride, B.W., Caldwell, T.H. \& Miller, S.P. 2009. In the determination of residual feed intake and association of infrared thermography with efficiency and ultrasound traits in beef bulls. Livestock Science 125: $22-30$.

Moore, K.L., Johnston, D.L. \& Burrow, H.M. 2005. Sire breed differences for net feed intake in feedlot finished beef cattle. Proceedings of the association for the advancement of animal breeding and genetics. 16: 76-79. Moore, S.S., Mujibi, F.D. \& Sherman, E.L. 2009. Molecular basis for residual feed intake in beef cattle. Journal of Animal Science. 87: E41-E47.

Nkrumah, J.D. Basarab, J.A., Price, M.A., Okine, E.K., Ammoura, A., Guercio, S., Hansen, C., Li, C., Benkel, B., Murdoch, B. \& Moore, S.S. 2004. Different measures of energetic efficiency and their phenotypic relationships with growth, feed intake, and ultrasound and carcass merit in hybrid cattle. Journal of Animal. Science. 82: 2451-2459.

Nkrumah, J. D., Basarab, J.A., Wang, Z., Li, C., Price, M.A., Okine, E.K., Crews, D.H. \& Moore, S.S. 2007. Genetic and phenotypic relationships of feed intake and measures of efficiency with growth and carcass merit of in beef cattle. Journal of Animal Science. 85:2711-2720.

Nkrumah, J. D., Okine, E. K., Mathison, G. W., Schmid, K., Li, C., Basarab, J. A., Price, M. A., Wang, Z. \& Moore, S. S. 2006. Relationships of feedlot feed efficiency, performance, and feeding behavior with metabolic rate, methane production, and energy partitioning in beef cattle. Journal of Animal Science. 84: 145-153. Okine, E.K., Basarab, J.A., Goonewardene, L.A., Mir, P., Mir, Z., Price, M.A., Arthur, P.F. \& Moore, S.S. 2003. Residual feed intake: what is it and how does it differ from traditional concepts of feed efficiency? Proceedings of the Canadian Society of Animal Science. CD-ROM communication. Webinar http://pubservices.nrc-cnrc.ca.

Pinares-Patiño, C. S., Baumont, R. \& Martin, D. R. 2004. Methane emissions by Charolais cows grazing a monospecific pasture of timothy at four stages of maturity. Canadian Journal of Animal Science. 78: 769-777. Prado-Cooper, M.J., Madden, R.D., Dillwith, J.W., Bailey, C.L., Wright, E.C., Krehbiel, C.R. Step, D.L. \& Wettenmann, R.P. 2009. Proteomic analyses in beef cows with low and high maintemance energy requirements. Journal Animal Science. E-Suppl. 2. 87: 296.

Richardson, E.C. \& Herd, R.M. 2004. Biological basis for variation in residual feed intake in beef cattle. 2. Synthesis of results following divergent selection. Australian Journal of Experimental Agriculture. 44:431-440. Richardson, E.C., Herd, R.M., Archer, J.A. \& Arthur, P.F. 2004. Metabolic differences in Angus steers divergently selected for residual feed intake. Australian Journal of Experimental Agriculture. 44:441-452.

Richardson, E.C., Herd, R.M., Oddy, V.H., Thompson, J.M., Archer, J.A. \&Arthur, P.F. 2001. Body composition and implications for heat production of Angus steer progeny of parents selected for and against residual feed intake. Australian Journal of Experimental Agriculture. 41:1065-1072.

Robinson, D. L. \& Oddy, V.H. 2004. Genetic parameters for feed efficiency, fatness, muscle area and feeding behaviour of feedlot finished beef cattle. Livestock Production Science. 90:255-270.

Schenkel, F.S., Miller, S.P. \& Wilton, J.W. 2003. Genetic parameters of feed efficiency, growth and carcass traits of beef bulls. Canadian Journal of Animal Science. 83: 617-618.

Schenkel, F. S., Miller, S.P. \& Wilton, J.W. 2004. Genetic parameters and breed differences for feed efficiency, growth and body composition traits of young beef bulls. Canadian Journal of Animal Science. 84:177185.

Tixier-Boichard, M.A., Borda, A. Renand, G. \& Bidanel, J.P. 2002. Residual food consumption as a tool to unravel genetic components of food intake. Proceedings of $7^{\text {th }}$ World Congress of Genetics Applied to Livestock Production, France. 31: 213-220.

Vinet, A., Krauss, D. Andre, C. \& Renand, G. 2008. Relations génétiques entre les capasités d'ingestion de taurillions, bœufs, génisses et vaches. 3R. 15 Journeés 3R. http://www.inst-elevage.asso.fr. 